\title{
Analysis of Simple Sequence Repeat Markers Linked to Submergence Tolerance on Newly Developed Rice Lines Derived from MR263 × Swarna-Sub1 \\ (Analisis Penanda Ulangan Jujukan Ringkas terhadap Titisan Padi Baharu Dibangunkan yang \\ Toleransi Tenggelam daripada Kacukan MR263 × Swarna - Subl)
}

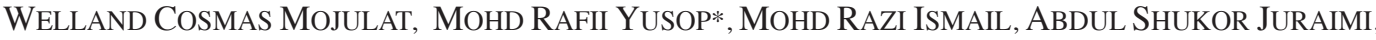 \\ ABDUl RAHIM HARUN, FAHIM AHMED, FATAH ABRo TANWEER \& MD. ABDUl LATIF
}

\begin{abstract}
Nowadays, in extreme changing environments, development of submergence tolerance variety is necessary for ensuring crop production stability where, it is known that Malaysian commercial rice varieties such as MR219, MR220 and MR263 were severely susceptible to submergence. First step towards the development of submergence tolerance variety starts with the breeding program by crossing MR263 and Swarna-Sub1. Marker-assisted selection (MAS) was carried out through the utilization of simple sequence repeats (SSR) markers, considering its reliability as pre-selection tools to conduct this research. $F_{1}$ generations plants were confirmed by tightly linked markers. In case of background study, out of 180 SSR markers, 38 were found polymorphic between two parents. Association of molecular markers and submergence tolerance were determined using Chi-square test. MR263 $\times$ Swarna-Sub1 $F_{2}$ lines were tested for Sub1 gene conformation using the markers RM8300 and RM219. These markers showed a good fit to the expected marker segregation ratio (1:2:1) in a Mendelian single gene model $(D F=1.0, \mathrm{p} \leq 0.05)$. Eleven homozygous lines with $\mathrm{Sub} 1$ gene out of 256 were selected for future development of submergence tolerant varieties. Eleven lines were selected based on phenotypic study and agronomic performance.
\end{abstract}

Keywords: Marker-assisted selection; rice; Sub1; submergence tolerance; SSR

\section{ABSTRAK}

Pembangunan varieti padi yang toleransi tenggelam adalah penting bagi memastikan kestabilan pengeluaran tanaman akibat perubahan melampau alam sekitar yang tidak menentu. Varieti padi komersial Malaysia seperti MR219, MR220 dan MR263 telah dikenal pasti terjejas teruk akibat tenggelam. Langkah pertama ke arah pembangunan varieti yang toleransi tenggelam bermula dengan program pembiakbakaan MR263 dan Swarna-Sub1. Dalam kajian ini, pemilihan berbantukan penanda (MAS) telah dijalankan dengan menggunakan penanda ulangan jujukan ringkas (SSR) yang disahkan kebolehpercayannya sebagai alat pra-pemilih. Generasi pokok $F$ telah disahkan oleh penanda yang terkait erat. Dalam kajian latar belakang, daripada 180 penanda SSR, 38 penanda adalah polimorfik antara kedua-dua induk. Hubungan antara penanda ulangan jujukan ringkas dan toleransi tenggelam ditentukan dengan menggunakan ujian Chi-square. Titisan $F_{2}$ MR263 × Swarna-Sub1 telah diuji untuk korformasi gen Sub1 dengan menggunakan penanda RM8300 dan RM219. Penanda ini menunjukkan keserasian yang baik dengan kadar segregasi yang dijangka (1:2:1) dalam model gen tunggal Mendel ( $D F=1.0, \mathrm{p} \leq 0.05$ ). Sebelas titisan homozigot yang mempunyai gen $\mathrm{Sub} 1$ telah dipilih daripada 256 titisan untuk pembangunan masa depan varieti padi yang toleransi tenggelam. Sebelas titisan ini dipilih berdasarkan kajian fenotip dan prestasi agronomi.

Kata kunci: Padi; pemilihan berbantukan penanda; Sub1; toleransi tenggelam; SSR

\section{INTRODUCTION}

Rain-fed lowlands account for about 25 million hectares of rice area in South and Southeast Asia. The total production of rice has also become static over the years with the gradual decrease of crop-growing area for non-rice crops, other enterprises and infra-structures. The static production of rice is still attributable to the lack of suitable improved cultivars for different agro-climatic conditions, particularly for unfavorable ecosystems. In order to increase total rice production, we must explore the development possibility of high yielding varieties with tolerance against abiotic stresses for unfavorable ecosystems. Among the abiotic stresses, submergence is one of the important factors in the flash flood prone rice growing environment. Catling (1992) defined submergence tolerance of a rice plant as its ability to survive 10-14 days of complete submergence and renew its growth when the water subsides.

Submergence tolerant varieties have been long developed but it is not widely adopted by the farmers because its lack of many desirable traits of widely grown varieties (MacKill 2006) such as high yield and short stature. Submergence tolerance in rice was reported to 
be a quantitative trait controlled by a major locus. The effect of environment on this trait was high in spite of its high heritability. Additive gene action was found more preponderant in the inheritance of the trait (Mishra et al. 1996; Mohanty \& Khush 1985).

The introgression of submergence tolerant Sub1 gene into susceptible rice variety improves submergence tolerance significantly, thus it has no negative side effect in terms of yield, harvest index and grain quality when grown under non-submerged condition (Xu et al. 2006). To date, no submergence tolerant local variety has been developed in Malaysia and also no report of submergence tolerance study on local variety have been found. MAS has previously been used in rice breeding to incorporate the bacteria blight resistance genes (Chan 2001; Chen 2000), blast resistance genes (Hasan et al. 2016; Miah et al. 2015) waxy gene (Zhou et al. 2003), fragrance gene (Lau et al. 2017) and submergence tolerance (Ahmed et al. 2016; Neeraja et al. 2007) into elite varieties. The markers used in this study to identify submergence tolerance lines are also used by Neeraja et al. (2007) and Toojinda et al. (2005). Molecular markers such as SSRs have been efficiently utilized in many crop improvement programs viz., hybrid identification, testing seed genetic purity and linkage mapping. Even though a single gene namely SublA controlling tolerance against submergence has been identified, the transfer of this gene through conventional breeding combined with MAS is still the most effective way to develop submergence tolerant rice cultivars (Xu et al. 2006). The effectiveness of MAS depends on the availability of closely linked markers and/or flanking markers for the target gene, the size of the population, the number of crosses and the position and number of markers for background selection (Frisch \& Melchinger 2005). The objectives of this study were to analyze SSR markers associated with submergence tolerant gene up to $\mathrm{F}_{2}$ generation derived from a cross between MR263 and Swarna-Sub1 varieties and, to select improved lines from the cross carrying the $S u b 1$ gene.

\section{MATERIALS AND METHODS}

\section{PLANTING MATERIALS AND CROSSING SCHEME}

The recipient variety was MR263, high yielding variety, identified as susceptible to submergence. Swarna-Sub1, submergence tolerant variety was used as the donor for $S u b 1$ gene. It is an improved submergence variety released in India with high yield. A single cross between the varieties MR263 and Swarna-Subl was performed to obtain $\mathrm{F}_{1}$ seeds. $\mathrm{F}_{1}$ seeds were tested with tightly linked SSR marker linked to $\mathrm{Subl}$ gene . Positive plants were planted again to obtain $\mathrm{F}_{2}$ seeds.

\section{DNA EXTRACTION}

DNA was extracted from young leaves of 4-week-old $F_{1}$ and the parental plants using a modified protocol as described by McCouch et al. (1988). The procedure involved grounding of $1 \mathrm{~g}$ leaf tissue and then transferred it into an Eppendorf tube containing $15 \mathrm{~mL}$ CTAB extraction buffer (100 mM Tris-Cl, pH 8.0, 25 mM EDTA, pH 8.0, 1.25 M $\mathrm{NaCl}$ and $30 \mu \mathrm{L} \beta$-mercapoethanol). It was then incubated in a hot water bath for $1 \mathrm{~h}$ at $65^{\circ} \mathrm{C}$ (gently shaken at 5 min interval). Then, $15 \mathrm{~mL}$ chloroform-isoamyl alcohol was added. The contents were mixed gently for 2-3 $\mathrm{min}$ and centrifuged at $5000 \mathrm{rpm}$ for $10 \mathrm{~min}$ at $25^{\circ} \mathrm{C}$ using centrifuge 5810 (Eppendorf, Germany). The supernatant was transferred to a fresh sterile $50 \mathrm{~mL}$ Falcon tube and 0.6 volume of ice-cold isopropanol was added. The DNA was pelleted by centrifugation at $12,000 \mathrm{rpm}$ for $1 \mathrm{~min}$ at room temperature. After centrifugation, the supernatant was discarded and the DNA pellet was washed twice with $70 \%$ ethanol. The pellets were air dried for $1 \mathrm{~h}$ and dissolved in $100 \mu \mathrm{L}$ of sterile TE buffer $(10 \mathrm{mM}$ Tris $\mathrm{HCl}, \mathrm{pH} 8.0$ and $1 \mathrm{mM}$ EDTA, $\mathrm{pH}$ 8.0). $2 \mu \mathrm{L}$ RNAse was added into each DNA samples to remove RNA.

Quantification of DNA was done using nanodrop spectropfotometry (ND1000 Spectrophotometer); followed by gel electophoresis using $1 \times$ TAE buffer at $5-8 \mathrm{~V} / \mathrm{cm}$ for $30 \mathrm{~min}$ on $1 \%$ agarose gel .Then it was visualized using an UV transluminator where, ethidium bromide was used as staining agent. The DNA sample was then kept in a freezer at $-20^{\circ} \mathrm{C}$ for polymerase chain reaction (PCR) analysis.

\section{POLYMERASE CHAIN REACTION}

PCR was carried out in a thermocycler (PTC-200 Peltier Thermal Cycler DNA Engine) using primers related to Subl gene. PCR reaction mix included the following: 40 ng template DNA, $100 \mu \mathrm{M}$ dNTPs $(0.2 \mathrm{mM}$ each of dATP, dTTP, dGTP and dCTP), $1.5 \mathrm{mM} \mathrm{MgCl} 2,1 \times$ PCR buffer (10 $\mathrm{mM}$ Tris- $\mathrm{HCl}$ and $50 \mathrm{mM} \mathrm{KCl}, \mathrm{pH} 8.3), 1.0 \mu \mathrm{M}$ of each primer and 0.2 U Taq DNA polymerase. PCR profile, started with initial denaturation at $94^{\circ} \mathrm{C}$ for $5 \mathrm{~min}$ followed by 35 cycles at $94^{\circ} \mathrm{C}$ for $30 \mathrm{~s}, 55^{\circ} \mathrm{C}$ for $30 \mathrm{~s}, 72^{\circ} \mathrm{C}$ for $30 \mathrm{~s}$ and a final extension at $72^{\circ} \mathrm{C}$ for $5 \mathrm{~min}$, followed by rapid cooling to $4^{\circ} \mathrm{C}$ prior to analysis. The PCR product was electrophoresed in a 3.0\% Metaphor agarose gel in 1× TBE buffer (0.05 M Tris, $0.05 \mathrm{M}$ boric acid and $1 \mathrm{mM}$ EDTA, $\mathrm{pH} 8.0)$ at $90 \mathrm{~V}$ for $1 \mathrm{~h}$ after it was mixed with with 2.5 $\mu \mathrm{L} 6 \times$ loading dye $(0.2 \%$ bromophenol blue, $0.2 \%$ xylene cyanol dye and $30 \%$ glycerol in a Tris-EDTA buffer) and visualized under UV light. PCR product will be observed on a UV transilluminator. The PCR products were scanned using the Bio-Imaging System (Chemi-Genius, USA) for further analysis.

\section{FOREGROUND, RECOMBINANT AND BACKGROUND STUDY}

One hundred and eighty SSR markers covering all the 12 chromosomes in rice genome were used for genotyping the parents MR263 and Swarna-Sub1. Eight markers were used for foreground and recombinant selection based on previous MAS program on rice (Iftekharuddaula et al. 2011; Neeraja et al. 2007; Septiningsih et al. 2009; Xu \& Mackill 1996) (Table 1). 
TABLE 1. Foreground and recombinant SSR Marker

\begin{tabular}{llll}
\hline \multicolumn{1}{c}{ Primer } & \multicolumn{1}{c}{ Primer Sequence (5'-3') } & \multicolumn{1}{c}{ Repeat motif } \\
\hline & \multicolumn{1}{c}{ F: forward primer } & \multicolumn{1}{c}{ reve primer } \\
RM219 & CGTCGGATGATGTAAAGCCT & CATATCGGCATTCGCCTG & $(\text { CT })_{17}$ \\
RM8300 & GCTAGTGCAGGGTTGACACA & CTCTGGCCGTTTCATGGTAT & $(\text { ACCATTAT })_{3}$ \\
RM23679 & TCACAGCTTAGTGCATGTTGAGC & GATTCACCTGGCAATGAGAACG & $(\text { AGAA })_{10}$ \\
RM23805 & GAGACAGATGTGTACGGTTTGGT & TTGACAAGGAAGGAGAAG & $(\mathrm{TG})_{13}$ \\
RM23915 & GAGGATCCTTACCATCAAACTTCG & CCAAGAACCTGCATTCTTCAAGG & $(\text { AC })_{15}$ \\
RM23958 & CTACCACTGTTCATTGTGTCTCG & GAATTGAAGGAGAAGCAGGAAGC & $(\text { CT })_{15}$ \\
ART5 & CAGGGAAAGAGATGGTGGA & TTGGCCCTAGGTTGTTCAG & N/A \\
Sub1C173 & AACGCCAAGACCAACTTCC & AGGAGGCTGTCCATCAGGT & N/A \\
\hline
\end{tabular}

\section{DATA ANALYSIS}

The markers were scored for presence or absence of the corresponding bands between two parents. The homozygous recipient allele, homozygous dominant allele and heterozygous allele were scored as 'A', ' $\mathrm{B}$ ' and ' $\mathrm{H}$ ', respectively. The marker data was analyzed using the software Graphical Genotyper (van Berloo 2008). Mendelian segregation ratio was analyzed by chi-square $(\chi 2)$ test. The chi-square analysis for the genotypic and phenotypic ratio was calculated using the formula, $\chi^{2}=(\mathrm{O}-\mathrm{E})^{2} / \mathrm{E}$ where, $\mathrm{O}$ is the observed value and $\mathrm{E}$ is the expected value.

\section{SCREENING FOR SUBMERGENCE TOLERANCE}

Phenotypical screening for submergence tolerance was done at the glasshouse at Ladang 10, UPM following standard protocols (Xu et al. 2000). Selected $\mathrm{F}_{2}$ seeds, along with their parents were grown in trays where FR $13 \mathrm{~A}$ were used as check variety. Fourteen days old seedlings were submerged for two weeks. After de-submergence, survival and recovery data were taken at 6 days and 30 days following standard protocol (IRRI 2002) for the confirmation of the Subl locus.

\section{RESULTS AND DISCUSSION}

PARENTAL POLYMORPHISM SURVEY USING SSR MARKERS

Out of 180 SSR primers, 38 primers showed polymorphism between two parents (Figure 1, Table 2). In this study, the frequency of polymorphic SSR markers was $21.11 \%$. Cuc et al. (2012) reported $12.6 \%$ frequency of polymorphic SSR markers. In another study between PRR78 and Pusa 1460, Basavaraj et al. (2010) reported a frequency of $17.47 \%$. A study of polymorphism in two parents, Bac Thom 7 and IR64, showed that $15.1 \%$ of the SSR markers were found to be polymorphic (Khanh et al. 2013).

\section{FOREGROUND SELECTION}

Rice microsatellite markers RM219, RM8300, RM23679, RM23805, RM23915, RM23958, ART5 and Subl C173 which

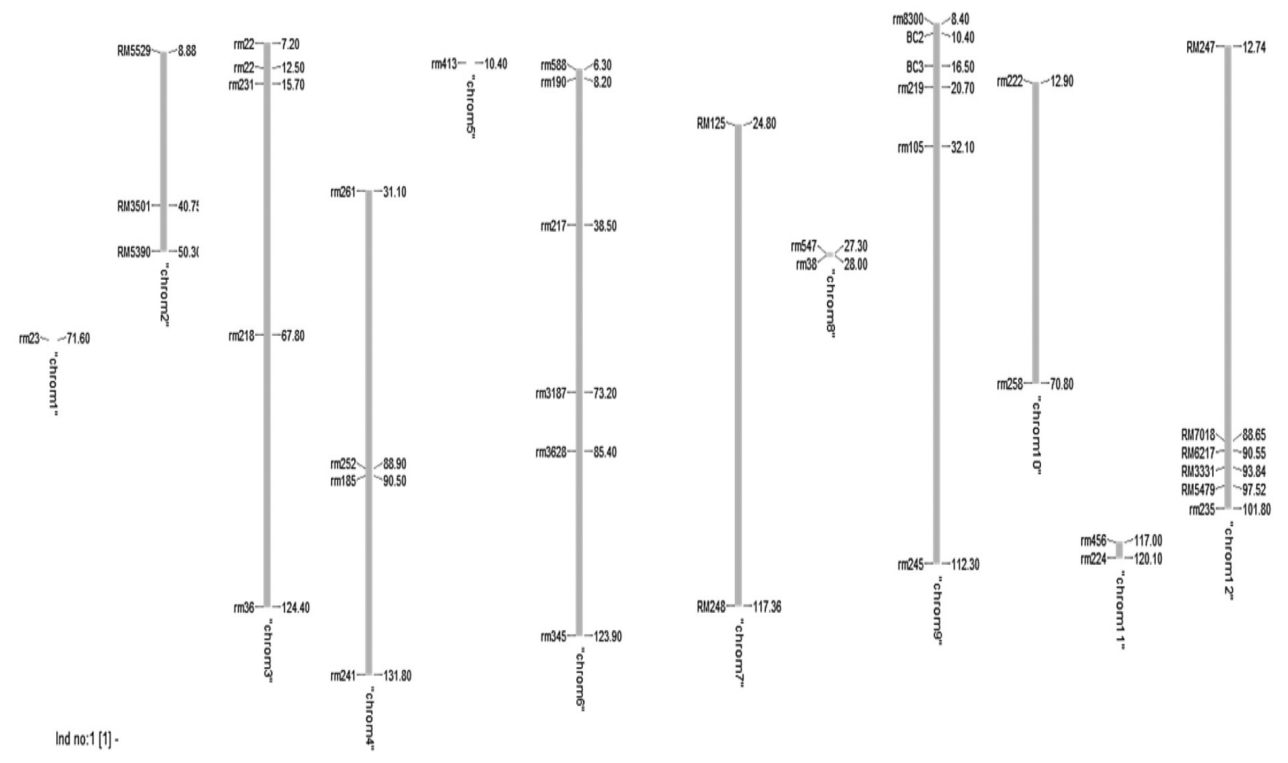

FIGURE 1. Chromosome wise distribution of each polymorphic marker between MR263 and Swarna-Sub1 
TABLE 2. List of polymorphic SSR markers with their chromosome location

\begin{tabular}{|c|c|c|c|}
\hline No. & Chromosome & SSR Primer & Location $(\mathrm{cM})$ \\
\hline 1 & 1 & RM23 & 71.6 \\
\hline 2 & 2 & RM5529 & 8.8 \\
\hline 3 & 2 & RM3501 & 40.75 \\
\hline 4 & 2 & RM5390 & 50.3 \\
\hline 5 & 3 & RM22 & 7.2 \\
\hline 6 & 3 & RM231 & 15.7 \\
\hline 7 & 3 & RM218 & 67.8 \\
\hline 8 & 3 & RM36 & 124.4 \\
\hline 9 & 4 & RM261 & 31.1 \\
\hline 10 & 4 & RM252 & 88.9 \\
\hline 11 & 4 & RM185 & 90.5 \\
\hline 12 & 4 & RM241 & 131.8 \\
\hline 13 & 5 & RM413 & 10.4 \\
\hline 14 & 6 & RM588 & 6.3 \\
\hline 15 & 6 & RM190 & 8.2 \\
\hline 16 & 6 & RM217 & 38.5 \\
\hline 17 & 6 & RM3187 & 73.2 \\
\hline 18 & 6 & RM3628 & 85.4 \\
\hline 19 & 6 & RM345 & 123.9 \\
\hline 20 & 7 & RM125 & 24.80 \\
\hline 21 & 7 & RM248 & 117.36 \\
\hline 22 & 8 & RM547 & 27.3 \\
\hline 23 & 8 & RM38 & 28 \\
\hline 24 & 9 & RM105 & 32.1 \\
\hline 25 & 9 & RM245 & 112.3 \\
\hline 26 & 9 & RM8300 & 8.40 \\
\hline 27 & 9 & $\mathrm{BC} 2$ & 10.40 \\
\hline 28 & 9 & $\mathrm{BC} 3$ & 16.50 \\
\hline 29 & 9 & RM219 & 20.70 \\
\hline 30 & 10 & RM222 & 12.9 \\
\hline 31 & 10 & RM258 & 70.8 \\
\hline 32 & 11 & RM456 & 117 \\
\hline 33 & 11 & RM224 & 120.1 \\
\hline 34 & 12 & RM235 & 101.8 \\
\hline 35 & 12 & RM5479 & 97.52 \\
\hline 36 & 12 & RM3331 & 93.84 \\
\hline 37 & 12 & RM6217 & 90.55 \\
\hline 38 & 12 & RM7018 & 88.65 \\
\hline
\end{tabular}

were previously found to be closely linked to $\mathrm{Subl}$ gene on chromosome 9 were surveyed for parental polymorphism. Out of these two markers RM8300 and RM219 showed clear polymorphism and were used for foreground selection in $\mathrm{F}_{1}$ and $\mathrm{F}_{2}$ populations.

In order to select $\mathrm{F}_{2}$ plants carrying the $\mathrm{Subl}$ gene, genomic DNA was isolated from all the $256 \mathrm{~F}_{2}$ individuals and genotyped using the SSR markers RM219 and RM8300. Eleven best $F_{2}$ lines based on their genotypic data were selected from $125 \mathrm{~F}_{2}$ heterozygotes plants on the basis of presence of Subl gene (Figures 2-4). In earlier study of MAS, few diagnostic markers were used to select submergence-tolerant varieties, such as markers RM23805, RM8300, RM219 (Xu et al. 2006). Introgression of QTLs associated with submergence tolerance into different varieties have been carried out by several researchers (Neeraja et al. 2007; Siangliw et al. 2003; Toojinda et al. 2005; Xu et al. 2004).
In $\mathrm{F}_{2}$ generation, recombinant selection was done to get recombinant at each side of the Subl QTL to reduce the size of the inserted segment. For the determination of the size of the Subl region of chromosome 9 one flanking markers were used in $\mathrm{F}_{2}$ generation. Neeraja et al. (2007) used RM316 $(1.8 \mathrm{cM})$ and RM219 $(11.7 \mathrm{cM})$ at the proximal and distal end, respectively, in case of development of Swarna-Sub1. Selection of flanking marker should be chosen to keep the donor segment as closely as possible to reduce the linkage drag (Hospital 2001). Young and Tanksley (1989) proposed the optimal number of population and the generation to obtain the double recombinant for closely linked markers. The distance between the two closest markers (RM8300 and RM219) at both sides of the Sub1 QTL was $12.3 \mathrm{cM}$. SSR markers were linked to $S u b l$ were analyzed for the alleles existing in $\mathrm{F}_{2}$ plants. All of these markers exhibited visible polymorphic bands and showed consistent band sizes between resistant 


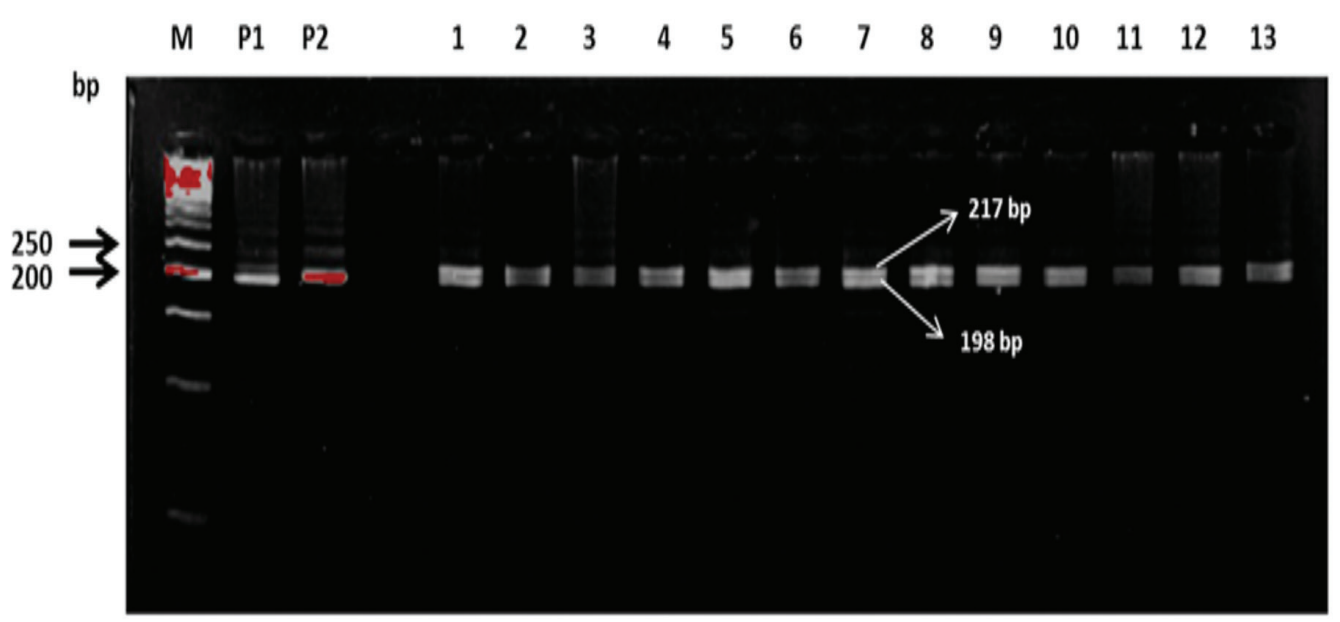

FIGURE 2. Banding pattern of $\mathrm{F}_{1}$ plants of MR263 $\times$ Swarna-Sub1 for RM8300 marker linked to Sub1 gene

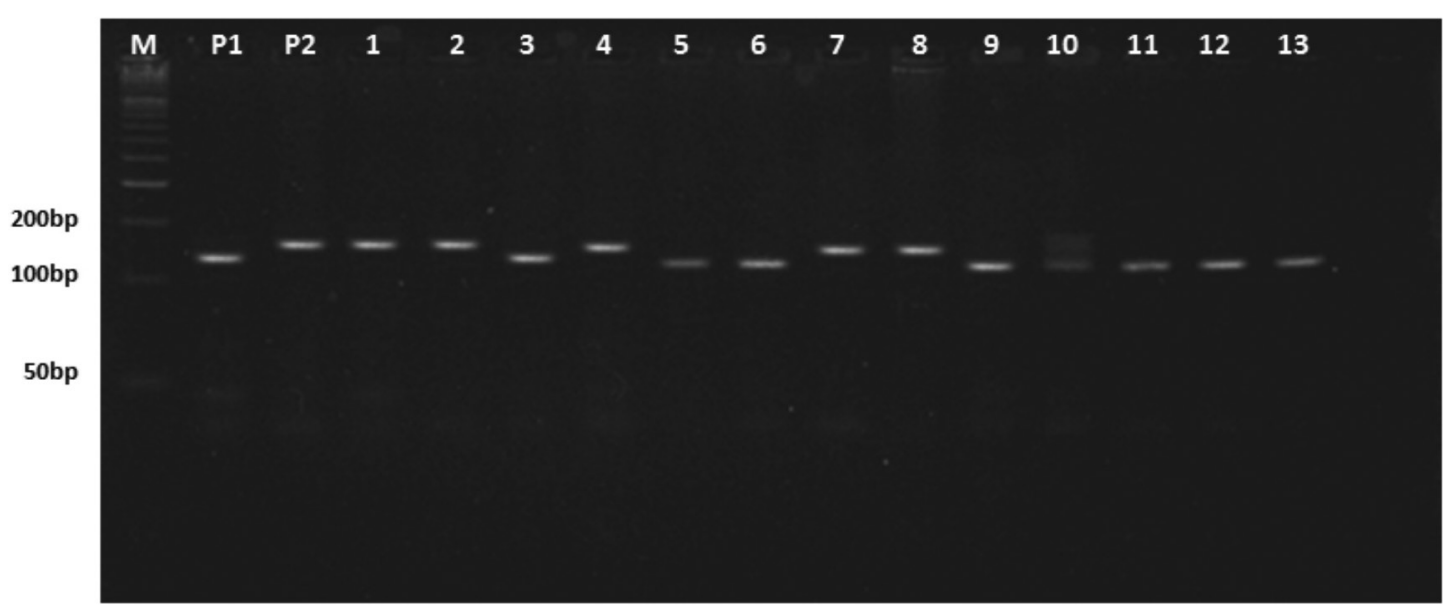

FIGURE 3. Banding pattern of $\mathrm{F}_{2}$ plants of MR263 $\times$ Swarna-Sub1 for RM8300 marker linked to Sub1 gene

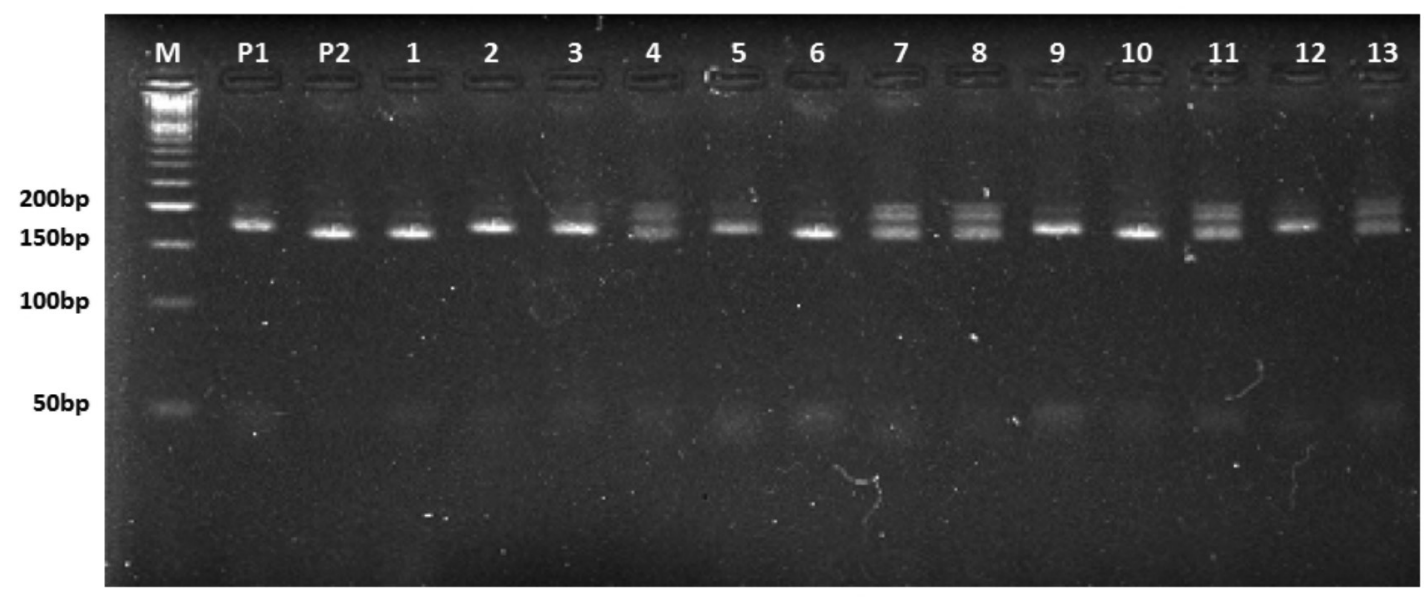

FIGURE 4. Banding pattern of $\mathrm{F}_{2}$ plants of MR263 × Swarna-Sub1 for RM219 marker linked to Sub1 gene 
or susceptible accessions. Segregation ratio for used markers is shown in Table 3. The segregation analysis showed that the $\mathrm{F}_{2}$ plants containg $\mathrm{Subl}$ gene associated with the markers RM219 and RM8300. These markers showed a good fit to the expected genotypic segregation ratio (1:2:1) in the Mendelian single gene model ( $\mathrm{Df}=1.0$, $p \leq 0.05)$. From this study, it was shown that the markers RM8300 and RM219 could be used for the introgression of the $S u b 1$ gene into MR263 rice variety which is prone to submergence stress.

\section{SUBMERGENCE SCREENING}

Selected 11 lines showed submergence tolerance and also recovery after desubmergence. MR263 did not recover from submergence stress, while resistant checks and all the selected lines showed a very good survival capacity and recovery. Selected lines along with their donor parent showed very good survival percentage (above 80\%), during testing on glass house. The above result confirms the presence of Subl on the selected lines (Table 4). In submergence screening at glasshouse all the selected lines showed tolerance, which is similar to its donor parent Swarna-Subl. In agronomical performance study, all the seleced newly developed lines showed the performance close to that of high yielding variety MR263.

\section{AGRONOMICAL PERFORMANCE OF $\mathrm{F}_{2}$ LINES}

Out of selected lines from $\mathrm{F}_{2}, 11$ were selected based on their agronomical characteristics in 2013-2014 seasons at Ladang 10 UPM, Malaysia. Agronomical performance of the 11 selected lines were evaluated regarding different yield and yield contributing factors. Significant variation

TABLE 3. Marker analysed in the $\mathrm{F}_{2}$ population derived from cross between MR $263 \times$ Swarna-Subl indicates that the observed $\mathrm{F}_{2}$ segregation ratios of this population were not significantly different from the expected 1:2:1 single dominant gene segregation

\begin{tabular}{|c|c|c|c|c|c|}
\hline \multirow{2}{*}{ Markers } & \multicolumn{3}{|c|}{ Marker segregation analysis (no. of lines observed) } & \multirow{2}{*}{$\chi^{2}(1: 2: 1)$} & \multirow{2}{*}{$p$ value } \\
\hline & A & $\mathrm{AB}=\mathrm{SG}$ & $\mathrm{B}$ & & \\
\hline RM219 & 70 & 133 & 53 & 2.65 & 0.265 \\
\hline RM23679 & 54 & 166 & 36 & 25.09 & $<0.001$ \\
\hline RM8300 & 69 & 125 & 62 & 0.52 & 0.771 \\
\hline RM23805 & 81 & 150 & 25 & 32.06 & $<0.001$ \\
\hline RM23915 & 73 & 142 & 41 & 11.06 & 0.004 \\
\hline
\end{tabular}

According to a model on asingle dominant gene, (A): Resistant; (B): Susceptible; and (AB or SG): Segregant. $\mathrm{df}=1.0 ; \chi^{2}(0.05,1)=3.84 ; \chi^{2}(0.01,1)=6.633$

TABLE 4. Submergence screening of MR263 $\times$ Swarna-Sub1 lines in field condition

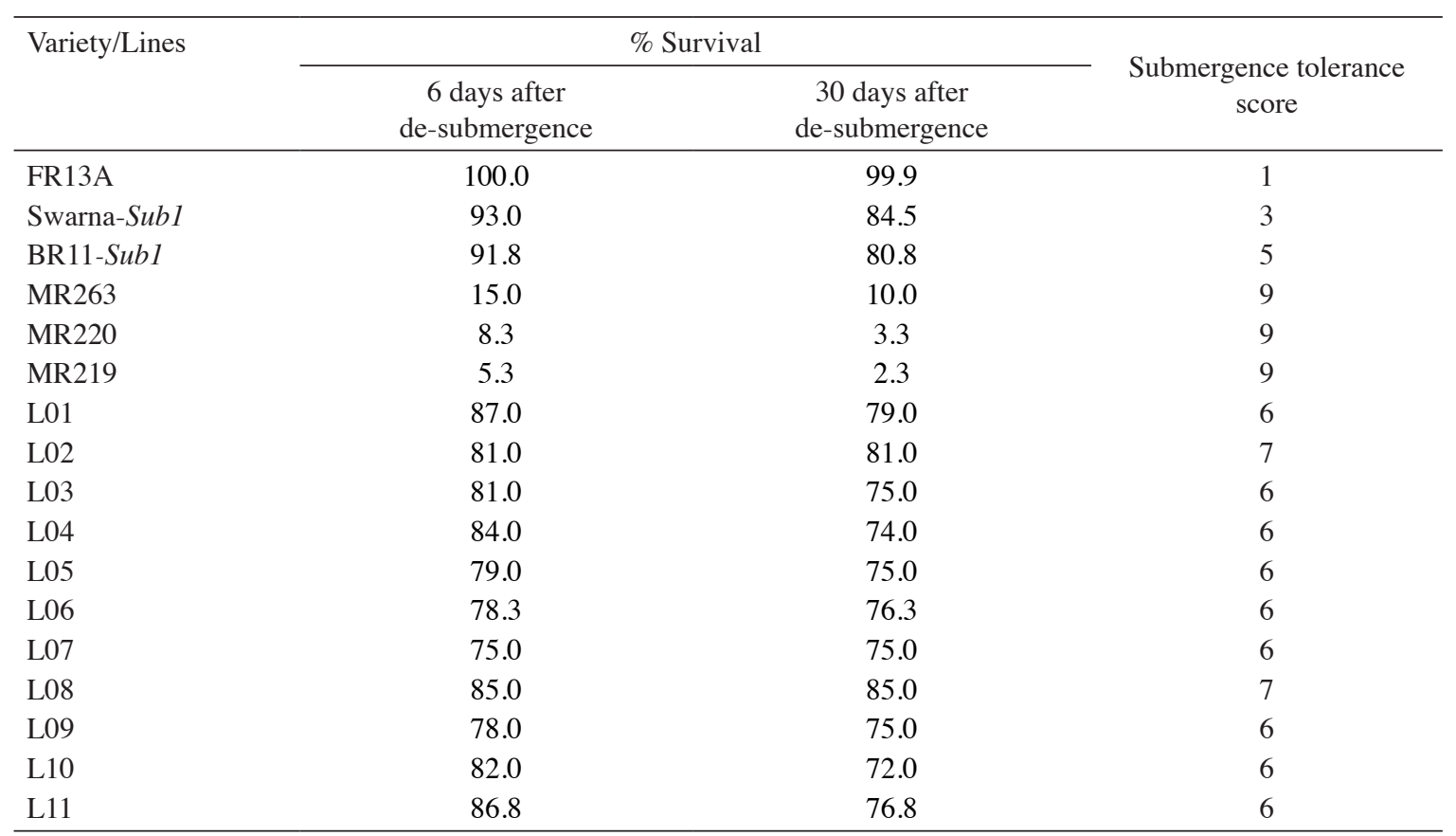

Score for tolerance after 6 days: 1 , erect dark green leaves, very little elongation; 3 , erect green leaves, little elongation; 5 , droopy, pale green leaves, moderate elongation; 7, long, pale green leaves, elongated, few survived; 9 , long whitish leaves, elongated, completely dead 
TABLE 5. Different Yield and yield contributing characters of the newly developed submergence tolerance lines

\begin{tabular}{lcccccccccc}
\hline & $\begin{array}{c}\text { Days of } \\
\text { maturation }\end{array}$ & $\begin{array}{c}\text { Plant } \\
\text { height }\end{array}$ & $\begin{array}{c}\text { Tiller } \\
\text { number/ } \\
\text { hill }\end{array}$ & $\begin{array}{c}\text { Panicle } \\
\text { number/ } \\
\text { hill }\end{array}$ & $\begin{array}{c}\text { Panicle } \\
\text { length }\end{array}$ & $\begin{array}{c}\text { Filled } \\
\text { grain }\end{array}$ & $\begin{array}{c}\text { Grain } \\
\text { length }\end{array}$ & $\begin{array}{c}\text { Grain } \\
\text { width }\end{array}$ & $\begin{array}{c}\text { 1000-grain } \\
\text { weight }\end{array}$ & $\begin{array}{c}\text { Yield/ } \\
\text { hill }\end{array}$ \\
\hline $\begin{array}{l}\text { MR263 } \\
\text { L05 (MR263- }\end{array}$ & 100.07 & 66.58 & 29.49 & 31.40 & 24.27 & 72.77 & 9.57 & 2.24 & 27.39 & 55.39 \\
$\begin{array}{l}\text { Sub1) } \\
\text { L09(MR263- }\end{array}$ & 99.63 & 66.10 & 25.56 & 27.89 & 26.18 & 58.46 & 9.29 & 2.20 & 26.22 & 53.01 \\
Sub1) & 110.34 & 70.19 & 25.80 & 27.89 & 26.18 & 60.30 & 8.84 & 2.31 & 24.65 & 49.84 \\
HSD (0.05) & 7.6 & 6.45 & 21.404 & 3.78 & 5.56 & 7.86 & 0.008 & 0.010 & 6.06 & 0.766 \\
\hline
\end{tabular}

was found among all the characters except grain width and grain length with the parent MR263 (Table 5).

\section{CONCLUSION}

In this study, the rapid and precision introgression of $\mathrm{Subl}$ gene into MR263 was done by $\mathrm{F}_{2}$ generation. The specific aim of the present study was to keep the donor segment size as small as possible with the help of flanking markers (recombinant selection) within $\mathrm{F}_{2}$ generation. Thirty eight out of 180 evenly distributed SSR markers were screened for parental polymorphism between MR263 and Swarna-Sub1 . RM8300 and RM219 showed clear polymorphism between the parental lines and it was used for foreground selection in $F_{1}$ and $F_{2}$ generations. Out of $256 F_{2}$ plants, 125 plants were heterozygous as identified by RM8300 and RM219. Only $11 \mathrm{~F}_{2}$ plants were selected considering the primers and agronomical performances. The selected plants were subjected for further submergence and morphological evaluation. The MAS approach described in this study was successfully used to introgress $S u b 1$ gene into MR263 and could be utilized to introgress Subl gene into other important Malaysian rice varieties with minimum introgression segment and within shorter time frame.

\section{ACKNOWLEDGEMENTS}

The research was funded by LRGS project under the Ministry of Higher Education, Malaysia. The authors are grateful to the Malaysian Agricultural Research and Development Institute (MARDI) Research Station in Seberang Perai, Penang for providing the research facilities.

\section{REFERENCES}

Ahmed, F., Rafii, M.Y., Ismail, M.R., Juraimi, A.S., Rahim, H.A. \& Tanweer, F.A. 2016. Recurrent parent genome recovery in different populations with the introgression of Subl gene from a cross between MR219 and Swarna-Sub1. Euphytica 207(3): 605-618.

Basavaraj, S., Singh, V.K., Singh, A., Singh, A., Singh, A., Anand, D., Yadav, S., Ellur, R.K., Singh, D. \& Krishnan, S.G. 2010. Marker-assisted improvement of bacterial blight resistance in parental lines of Pusa RH10, a superfine grain aromatic rice hybrid. Mol. Breed. 26(2): 293-305.
Catling, H.D. 1992. Rice in Deep Water. London: The Macmillan Press Ltd.

Chen, H. 2001. Population structure of Pyricularia grisea from Central and Southern China and comparative mapping of QTL for blast-and bacterial blight-resistance in Rice and Barley. $\mathrm{PhD}$ thesis. Huazhong Agriculture University, Wuhan, China.

Chen, S., Lin, X.H., Xu, C.G. \& Zhang, Q. 2000. Improvement of bacterial blight resistance of Minghui 63', an elite restorer line of hybrid rice, by molecular marker-assisted selection. Crop Sci. 40: 239-244.

Cuc, L.M., Huyen, L.T., Hien, P.T., Hang, V.T., Dam, N.Q., Mui, P.T., Quang, V.D., Ismail, A.M. \& Ham, L.H. 2012. Application of marker assisted backcrossing to introgress the submergence tolerance QTL SUB1 into the Vietnam elite rice variety-AS996. Amer. J. Plant Sci. 3(4): 528-536.

Frisch, M. \& Melchinger, A.E. 2005. Selection theory for markerassisted backcrossing. Genetics 170(2): 909-917.

Hasan, M.M., Rafii, M.Y., Ismail, M.R., Mahmood, M., Alam, M.A. \& Rahim, H.A. 2016. Introgression of blast resistance genes into the elite rice variety MR263 through markerassisted backcrossing. J. Sci. Food Agr. 96(4): 1297-1305.

Hospital, F. 2001. Size of donor chromosome segments around introgressed loci and reduction of linkage drag in markerassisted backcross programs. Genetics 158(3): 1363-1379.

Iftekharuddaula, K., Newaz, M., Salam, M.,Ahmed,H., Mahbub, M., Septiningsih, E., Collard, B., Sanchez, D., Pamplona, A. \& Mackill, D.J. 2011. Rapid and high-precision marker assisted backcrossing to introgress the SUB1 QTL into BR11, the rainfed lowland rice mega variety of Bangladesh. Euphytica 178(1): 83-97.

IRRI. 2002. Standard Evaluation System for Rice. Philippines: International Rice Research Institute.

Khanh, T.D., Linh, T.H. \& Xuan, T.D. 2013. Rapid and highprecision marker assisted backcrossing to introgress the SUB1 QTL into the Vietnamese elite rice variety. J. Plant Breed. Crop Sci. 5(2): 26-33.

Lau, W.C.P., Rafii, M.Y., Ismail, M.R., Asfaliza, R. \& Miah, G. 2017. Development of advanced fragrant rice lines from MR269 $\times$ Basmati 370 through marker-assisted backcrossing. Euphytica 213(1): 11. doi:10.1007/s10681-016-1794-z.

Mackill, D.J. 2006. Breeding for resistance to abiotic stresses in rice: The value of quantitative trait loci. In Plant breeding: The Arnel R. Hallauer International Symposium, edited by Lamkey, K.R. \& Lee, M. New York: Blackwell Publishing. pp. 201-212.

McCouch, S.R., Kochert, G., Yu, Z.H., Wang,Z.Y., Khush, G.S., Coffman, W.R. \& Tanksley, S.D. 1988. Molecular mapping of rice chromosomes. Theor. Appl. Genet. 76(6): 815-829. 
Miah, G., Rafii, M.Y., Ismail, M.R., Puteh, A.B., Rahim, H.A. \& Latif, M.A. 2015. Recurrent parent genome recovery analysis in a marker-assisted backcrossing program of rice (Oryza sativa L.). C. R. Biol. 338(2): 83-94.

Mishra, S., Senadhira, D. \& Manigbas, N. 1996. Genetics of submergence tolerance in rice (Oryza sativa L.). Field Crops Res. 46(1): 177-181.

Mohanty, H.K. \& Khush, G.S. 1985. Diallel analysis of submergence tolerance in rice, Oryza sativa L. Theor. Appl. Genet. 70(5): 467-473.

Neeraja, C.N., Maghirang-Rodriguez, R., Pamplona, A., Heuer, S., Collard, B.C., Septiningsih, E.M., Vergara, G., Sanchez, D., Xu, K., Ismail, A.M. \& Mackill, D.J. 2007. A markerassisted backcross approach for developing submergencetolerant rice cultivars. Theor. Appl. Genet. 115(6): 767-776.

Septiningsih, E.M., Pamplona, A.M., Sanchez, D.L., Neeraja, C.N., Vergara, G.V., Heuer, S., Ismail, A.M. \& Mackill, D.J. 2009. Development of submergence-tolerant rice cultivars: The Sub1 locus and beyond. Ann. Bot. 103(2): 151-160.

Siangliw, M., Toojinda, T., Tragoonrung, S. \& Vanavichit, A. 2003. Thai jasmine rice carrying QTLch9 (SubQTL) is submergence tolerant. Ann. Bot. 91(2): 255-261.

Toojinda, T., Tragoonrung, S., Vanavichit, A., Siangliw, J.L., Pa-In, N., Jantaboon, J., Siangliw, M. \& Fukai, S. 2005. Molecular breeding for rainfed lowland rice in the Mekong region. Plant Prod. Sci. 8(3): 330-333.

van Berloo, R. 2008. GGT 2.0: Versatile software for visualization and analysis of genetic data. J. Hered. 99(2): 232-236.

Xu, K., Deb, R. \& Mackill, D.J. 2004. A microsatellite marker and a codominant PCR-based marker for marker-assisted selection of submergence tolerance in rice. Crop Sci. 44(1): 248-253.

Xu, K. \& Mackill, D.J. 1996. A major locus for submergence tolerance mapped on rice chromosome 9. Mol. Breed. 2(3): 219-224.

Xu, K., Xu, X., Fukao, T., Canlas, P., Maghirang-Rodriguez, R., Heuer, S., Ismail, A.M., Bailey-Serres, J., Ronald, P.C. \& Mackill, D.J. 2006. SublA is an ethylene-response-factorlike gene that confers submergence tolerance to rice. Nature 442(7103): 705-708.

Xu, K., Xu, X., Ronald, P.C. \& Mackill, D.J. 2000. A highresolution linkage map of the vicinity of the rice submergence tolerance locus Sub1. Mol. Gen. Genet. 263(4): 681-689.

Young, N. \& Tanksley, S. 1989. Restriction fragment length polymorphism maps and the concept of graphical genotypes. Theor. Appl. Genet. 77(1): 95-101.
Zhou, P.H., Tan, Y.F., He, Y.Q., Xu, C.G. \& Zhang, Q. 2003. Simultaneous improvement for four quality traits of Zhenshan 97, an elite parent of hybrid rice, by molecular markerassisted selection. Theor. Appl. Genet. 106(2): 326-331.

Welland Cosmas Mojulat, Mohd Rafii Yusop*,

Mohd Razi Ismail, Abdul Shukor Juraimi, Fahim Ahmed

\& Fatah Abro Tanweer

Department of Crop Science, Faculty of Agriculture

Universiti Putra Malaysia

43400 UPM Serdang, Selangor Darul Ehsan

Malaysia

Mohd Rafii Yusop* \& Mohd Razi Ismail Institute of Tropical Agriculture and Food Security Universiti Putra Malaysia

43400 UPM Serdang, Selangor Darul Ehsan Malaysia

Abdul Rahim Harun

Agrotechnology and Bioscience Division

Malaysian Nuclear Agency, Bangi

43000 Kajang, Selangor Darul Ehsan

Malaysia

Fatah Abro Tanweer

Department of Plant Breeding and Genetics

Faculty of Crop Production

Sindh Agriculture University Tandojam, Sindh

Pakistan

Md. Abdul Latif

Bangladesh Rice Research Institute (BRRI)

Gazipur, Dhaka

Bangladesh

*Corresponding author; email: mrafii@upm.edu.my

Received: 12 January 2016

Accepted: 24 September 2016 